\title{
PENGARUH PENGGUNAAN TEPUNG DAUN Moringa oleifera TERHADAP TINGKAT PEMANFAATAN PROTEIN PAKAN DAN PERTUMBUHAN IKAN LELE DUMBO (Clarias gariepinus) SEBAGAI SUMBER BELAJAR BIOLOGI
}

\section{Rahmanda Fitriawan}

\author{
SMA Al Hidayah Way Seputih Lampung Tengah \\ Email: rahmandafitriawan93@gmail.com
}

\begin{abstract}
Leaf of Moring a oleifera represent the source of amino acid which necessary for body. One leaf glass of Moringa oleifera pregnant of equivalent with protein of protein found on 100 flesh gram. Protein content in leafflour of Moringa oleifera can reach $35 \%$ can become altemative of is source of potential protein to overcome the problems. With protein content at leafflour of Moringa oleifera which is high enough, so that can fulfill requirement of protein for the growth of fish of African catfish. This research is conducted with method of experiment where this research is done to know influence of leaf flour of Moringa oleifera to growth of fish of African catfish by entangling 1 control and four treatment. Feed the used is feed palette of have protein rate to $\pm 30 \%$. Treatment of control of feed without given by leaf flour of Moringa oleifera, behavioral 1 feed by $2.5 \%$ leafflour of Moringa oleifera, treatment two feed by $5.0 \%$ leaf flour of kelor, treatment three feed by $7.5 \%$ leaf flour of Moringa oleifera, treatment four feed by $10 \%$ leaf flour of Moringa oleifera. This research use Complete Random Design ( RAL) got by result of research of its its his value $0.457>0.05$ and $0.176>0.05$ and also $0.060>0,05$ meaning its value of it bigger than $\alpha=0.05$ so that $\mathrm{HO}$ accepted by its meaning of giving of leafflour of Moringa oleifera have an effect on to exploiting of protein offeed and growth offish of African catfish.
\end{abstract}

Kata Kunci: Sumber Belajar, Daun Moringa oliefera, Lele Dombo

\section{PENDAHULUAN}

Pemberian

pakan dalam

memelihara ikan lele merupakan kegiatan rutin yang teratur dilakukan, akan tetapi menghabiskan jumlah pakan besar (Ghufron \& Kardi, 2010). Dalam memelihara ikan lele selain pemberian pakan yang tepat, penggunaan pakan alternatif atau alami juga sangat dibutuhkan untuk menekan penggunaan pakan konvesional. Menurut Ghufron \& Kardi (2010) pakan buatan untuk ikan lele harus mengandung nutrisi yang cukup untuk memacu pertumbuhannya. Nutrisi yang memadai juga dapat membuat ikan tumbuh optimal dan memiliki kekebalan tubuh yang cukup baik. Pakan yang mengandung protein rendah akan menghambat laju pertumbuhan ikan. Untuk pertumbuhan optimal, ikan lele membutuhkan pakan buatan atau pelet yang mengandung protein antara $25-35 \%$ dan untuk memicu pertumbuhan lele, diperlukan pelet dengan kandungan protein 35$40 \%$. 
Penggunaan pakan alternatif yang efektif yang tidak berdampak buruk untuk ikan maupun konsumen sebagai penunjang pemenuhan gizi ikan lele dumbo. Pakan alternatif yang digunakan harus memenuhi kebutuhan gizi ikan lele dumbo dalam memacu pertumbuhannya. Kandungan protein dalam tepung daun kelor bisa mencapai 35\% bisa menjadi alternatif sumber protein yang potensial untuk mengatasi permasalahan tersebut (Kholis, \& Fariz 2010). Dengan kandungan protein pada tepung daun kelor yang cukup tinggi, sehingga dapat memenuhi kebutuhan protein untuk pertumbuhan ikan lele.

Pemberian atau penambahan nutrisi pada ikan lele merupakan salah satu faktor penting dalam mendukung pertumbuhan ikan. Hal ini merupakan salah satu faktor eksternal yang dipelajari oleh peserta didik pada materi Pertumbuhan dan Perkembangan. Seperti halnya pada penelitian ini yang dapat digunakan untuk mempelajari materi Pertumbuhan dan Perkembangan. Pendidikan yang diintegrasikan dengan nilai-nilai kehidupan sehari-hari akan lebih realitas, lebih kontekstual, dan lebih bermakna bagi peserta didik. Salah satu indikator bahwa peserta didik dikatakan memiliki kecakapan hidup apabila setelah tidak sekolah yang bersangkutan sanggup dan terampil menghadapi masalah kehidupan dan mampu menyikapi kehidupannya (Nuraini, 2012).

Indikator kecakapan hidup itu selaras dengan kurikulum 2013 yaitu menuntun peserta didik untuk mengembangkan sikap, kemampuan dan keterampilan untuk diterapkan dalam berbagai situasi di sekolah dan lingkungan. Agar terlihat lebih menarik dan mudah dipahami maka sumber belajar dalam penelitian ini dibuat dalam bentuk media pembelajaran. Media pembelajaran yang digunakan bukan hanya buku dan guru saja, akan tetapi media belajar harus dapat menarik dan membuat peserta didik lebih aktif dalam kegiatan pembelajaran serta efektif dan efisein karena media belajar yang baik akan mendukung tercapainya tujuan pembelajaran.

\section{METODE}

Penelitian ini merupakan penelitian kuantitatif dimana menggunakan 4 perlakuan dan satu kontrol yang dilakukan di Desa Sri Basuki, Kecamatan Seputih Banyak, Kabupaten Lampung Tengah, Provinsi Lampung. Penelitian yang telah dilakukan mengukur beberapa parameter yaitu panjang, berat ikan serta laju pertumbuhan relatifnya dan pemanfaatan protein pakan.

Penelitian ini dilakukan dengan metode ekperimen dimana penelitian ini dilakukan untuk mengetahui pengaruh tepung daun kelor terhadap pertumbuhan ikan lele dumbo dengan melibatkan 1 kontrol dan empat perlakuan. Penelitian ini menggunakan Rancangan Acak Lengkap (RAL), karena penelitian ini dilakukan pada tempat yang homogen. Pakan yang digunakan adalah pakan pelet berkadar protein $\pm 30 \%$ (Amalia dkk, 2013). Perlakuan kontrol pakan tanpa diberi tepung daun kelor, perilaku 1 pakan dengan 2,5\% tepung daun kelor, 
perlakuan dua pakan dengan 5,0\% tepung daun kelor, perlakuan tiga pakan dengan $7,5 \%$ tepung daun kelor, perlakuan empat pakan dengan $10 \%$ tepung daun kelor (Sjofjan, 2008).

\section{HASIL DAN PEMBAHASAN}

Tabel 1. Data Hasil Penelitian.

\begin{tabular}{ccccccc}
\hline \multirow{2}{*}{ Variabel } & \multirow{2}{*}{ Ulang } & \multicolumn{5}{c}{ Perlakuan } \\
\cline { 2 - 7 } & & $\mathbf{1}$ & $\mathbf{2}$ & $\mathbf{3}$ & $\mathbf{4}$ & $\mathbf{5}$ \\
\hline \multirow{3}{*}{ Panjang Ikan $(\mathrm{cm})$} & 1 & 21.86 & 21.76 & 22.0 & 21.56 & 21.8 \\
\cline { 2 - 7 } & 2 & 21.74 & 22.38 & 21.88 & 22.34 & 22.26 \\
\cline { 2 - 7 } & 3 & 21.02 & 21.86 & 21.8 & 21.86 & 21.9 \\
\hline \multirow{2}{*}{ Berat Ikan (gram) } & 1 & 115.4 & 118.4 & 119.0 & 115.0 & 117.2 \\
\cline { 2 - 7 } & 2 & 116.2 & 123.6 & 117.0 & 122.8 & 119.4 \\
\cline { 2 - 7 } Pemanfaatan Protein & 3 & 111.8 & 117.6 & 117.8 & 120.2 & 118.4 \\
\cline { 2 - 7 }$(\%)$ & 1 & 2.5 & 2.9 & 2.7 & 2.3 & 2.2 \\
\cline { 2 - 7 } & 3 & 2.5 & 3.1 & 2.6 & 2.5 & 2.2 \\
\hline \multirow{2}{*}{$\begin{array}{c}\text { Laju Pertumbuhan } \\
\text { Relatif (\%/hari) }\end{array}$} & 1 & 7.9 & 8.2 & 8.2 & 7.9 & 8.1 \\
\cline { 2 - 7 } & 2 & 8 & 8.6 & 8 & 8.5 & 8.2 \\
\hline
\end{tabular}

\section{Panjang Tubuh Ikan Lele Dumbo}

Berdasarkan hasil nilai signifikansinya $0,457>0,05$, yang berarti nilai signifikansinya lebih besar dari $\alpha=0,05$ sehingga $\mathrm{H}_{0}$ diterima artinya pemberian tepung daun kelor berpengaruh terhadap pertumbuhan panjang tubuh ikan lele dumbo.

\section{Berat Tubuh Ikan Lele Dumbo}

Berdasarkan hasil nilai signifikansinya $0,176>0,05$, yang berarti nilai signifikansinya lebih besar dari $\alpha=0,05$ sehingga $\mathrm{H}_{0}$ diterima artinya pemberian tepung daun kelor berpengaruh terhadap berat tubuh ikan lele dumbo.

\section{Pemanfaatan Protein Pakan}

Berdasarkan hasil nilai signifikansinya $0,000>0,05$, yang berarti nilai signifikansinya lebih besar dari $\alpha=0,05$ sehingga $\mathrm{H}_{0}$ diterima artinya pemberian tepung daun kelor berpengaruh terhadap pemanfaatan protein pakan.

1. Pengaruh Penggunaan Tepung Daun Kelor (Moringa oleifera) Dalam Pakan Terhadap Pertumbuhan Ikan Lele Dumbo (Clarias gariepinus)

Berdasarkan hasil uji hipotesis anava didapatkan nilai Sig. $0,457>0,05$ dan 0,176>0,05 sehingga tolak $\mathrm{H}_{0}$ dan terima $\mathrm{H}_{1}$ berarti terdapat pengaruh terhadap pertumbuhan ikan lele dumbo (Clarias gariepinus). Ini tidak terlepas dari kandungan daun kelor yang memiliki kandungan gizi yang cukup baik. Dimana kandungan protein dalam tepung daun kelor bisa mencapai 35\% (Kholis \& Fariz, 2010). Ini dapat mencukupi kebutuhan protein ikan lele dumbo (Clarias gariepinus) karena menurut Ghufron \& Kardi (2010) ikan lele membutuhkan kandungan protein antara 25 sampai 35 
\% pada pakan untuk pertumbuhan optimal, sedangkan untuk memicu pertumbuhan ikan lele membutuhkan pelet dengan kandungan protein 35 sampai $40 \%$. Sehingga tepung daun kelor pada penelitian ini yang di buktikan dengan uji hipotesis bahwasanya pemberian pelet dari tepung daun kelor mempengaruhi pertumbuhan pada ikan lele dumbo (Clarias gariepinus).

\section{Pengaruh Tepung Daun Kelor Terhadap Hasil Pemanfaatan Protein Pakan}

Pengaruh

penggunaan

tepung daun kelor sebagai pakan ikan lele terhadap efektifitas pemanfaatan protein pakan dapat dilihat pada Tabel 1. dimana pada variabel pemanfaatan protein pakan pada perlakuan 2 (pakan dengan $2,5 \%$ tepung daun kelor) memiliki nilai yang tertinggi yaitu $2.96 \%$ di bandingkan dengan perlakuan yang lain dimana pada perlakuan 1 (kontrol) rerata pertumbuhan $2.46 \%$, pada perlakuan 3 (pakan dengan 5,0\% tepung daun kelor) hanya $2.66 \%$ dan perlakuan 4 (pakan dengan 7,5\% tepung daun kelor) $2.4 \%$ serta perlakuan 4 (pakan dengan 10\% tepung daun kelor) $2.2 \%$. Berdasarkan hasil penelitian diduga perlakuan 2 (pakan dengan 2,5\% tepung daun kelor) dosis yang cukup untuk pertumbuhan ikan lele dumbo sehingga pemanfaatan protein sangat efisien. Protein yang terkandung dalam pakan sangat mempengaruhi pertumbuhan. Pakan dengan kandungan protein optimal dapat menghasilkan pertumbuhan maksimal. ini juga tidak terlepas dari kandungan yang ada di dalam daun kelor selain mengandung protein yang cukup tinggi salah satu faktor yang mempengaruhi efisiensi pemanfaatan protein pakan adalah kandungan vitamin $\mathrm{C}$ yang cukup tinggi dimana menurut Darseno (2010) Vitamin C tersedia dalam jumlah yang cukup, pembentukan kolagen akan normal dan ini mendukung pertumbuhan dan akhirnya berpengaruh pada efisiensi pemanfaatan protein akan meningkat sehingga tercapai pertumbuhan secara optimal.

\section{Analisis Potensi Hasil Penelitian untuk Sumber Belajar Biologi}

Jembatan penghubung antar penelitian yang dilakukan oleh peneliti dengan dunia pedidikan adalah dengan analisis potensi hasil penelitian untuk menjadi sumber belajar, dimana nantinya dalam tahap ini penelitian yang sudah dilakukan akan ditelaah untuk menjadi sumber belajar yang baik untuk peserta didik. sehingga nantinya peserta tidak hanya paham dalam konsep dan teori tetapi juga tahu bagaimana mengaplikasikannya konsep dan teori tersebut dalam memecahkan masalah dikehidupan sehari-hari. Berikut terdapat penjabaran mengenai analisis potensi penelitian sebagai sumber belajar biologi yaitu mencakup kejelasan potensi, kesesuaian dengan tujuan pembelajaran, kejelasan sasaran, kejelasan informasi yang diungkap, dan kejelasan perolehan yang diharapkan (Munajah dkk, 2015).

Berdasarkan pada hasil analisis potensi sumber belajar dalam penelitian ini, dapat disimpulkan bahwa telah memenuhi syarat untuk dijadikan sebagai sumber belajar biologi yang mencakup kejelasan potensi, kesesuaian dengan tujuan 
pembelajaran, kejelasan sasaran, kejelasan informasi yang diungkap, dan kejelasan perolehan yang diharapkan.

\section{KESIMPULAN}

Tepung daun kelor (Moringa oleifera) dapat digunakan dalam pakan karena berpengaruh terhadap pertumbuhan ikan lele dumbo (Clarias gariepinus) dan memiliki pemanfaatan protein sebagai pakan. Pakan dengan 2,5\% tepung daun kelor memiliki pengaruh yang terbaik terhadap pertumbuhan ikan lele dumbo (Clarias gariepinus) dan Pemanfaatan Protein Pakan. Hasil penelitian berpotensi dibuat sebagai sumber belajar biologi berupa poster.

\section{DAFTAR RUJUKAN}

Amalia, R., Subandiyono, \& Endang, A. 2013. Pengaruh Penggunaan Papain Terhadap Tingkat Pemanfaatan Protein Pakan dan Pertumbuhan Lele Dumbo. Jurnal of Aquaculture Management And Technology. Vol. 2. No. 1.

Darseno. 2010. Budidaya dan Bisnis Lele. Jakarta: Agromedia Pustaka.

Ghufron, M \& Kardi, H. 2010. Budidaya Ikan Lele Dikolam Terpal. Yogyakarta. ANDI.
Kholis, N. \& Fariz, H. 2010. Pengujian Bioassay Biskuit Balita Yang Disuplementasi Konsentrat Protein Daun Kelor (Moringa oleifera) Pada Model Tikus Malnutrisi. Jurnal Teknologi Pertanian Vol. 11 No. 3 Hal. 144-151.

Munajah., M. J. Susilo. 2015. Potensi Sumber Belajar Biologi SMA Kelas X Materi Keanekaragaman Tumbuhan Tingkat Tinggi di Kebun Bintang Gembira Loka. JUPEMASI-PBIO. Vol. 1 No. 2 Tahun 2015. ISSN: 2407-1269.

Nuraini, S. 2012. Upaya Meningkatkan Kecakapan Hidup dan Hasil Belajar Biologi Menggunakan Model Pembelajaran Problem Based Learning pada Siswa Kelas $\mathrm{X}_{2}$ SMA Paramarta 1 Seputih Banyak Tahun Pelajaran 2012/2013. Skripsi Tidak Diterbitkan. Metro. UM Metro.

Sjofjan, O. 2008. Efek penggunaan tepung daun kelor (Moringa oleifera) dalam pakan terhadap penampilan produksi ayam pedaging. Prosiding Seminar Nasional Teknologi Peternakan dan Veteriner. 649-656. 